\title{
GENERATIONAL ACCOUNTS AND DEMOGRAPHIC DIVIDEND IN RUSSIA
}

\author{
MIKHAIL DENISENKO, VLADIMIR KOZLOV
}

\begin{abstract}
The paper presents a modern methodology for estimating the impact of different age groups on the production and distribution of national income, called national transfer (generational) accounts. The human economic lifecycle is divided into stages defined by the ratio of labour income to consumption. In middle ages, gained income is higher than current consumption. The resulting surplus of resources is supposed to cover the income deficit in older and younger age groups. Estimates of the deficit or surplus at different ages are made for the Russian population for 2013 based on the results of age profiles taken from administrative sources and surveys. In the paper we also estimate the projected changes in the lifecycle deficit under different demographic development scenarios. Age profiles of labour income and consumption are used to calculate the effective economic support and the influence of demographic changes in Russia on economic growth rates in the near future.
\end{abstract}

Key words: economic lifecycle, national transfer accounts, income, consumption, ageing, effective economic support, demographic dividend.

\section{INTRODUCTION}

In recent decades, the world has experienced significant demographic changes, which are manifested in a decrease in fertility, an increase in life expectancy, intensive international migration and, as a result, the transformation of the age composition of the population. In some countries where the demographic transition is close to completion or completed, a process of demographic aging is underway. A steady increase in the proportion of people at older ages in the total population is a challenge for these countries, whose social institutions were formed in the period of their "demographic youth". In other countries, where fertility decline began relatively recently, the proportion of young persons of working age is increasing and the proportion of children is decreasing. With other things being equal, such an optimization of the age structure may lead to a demographic dividend, as was recently the case in China or other countries of Southeast Asia.

According to some estimates, the demographic dividend in East Asia accounts for between one-fourth and two-fifths of economic growth in the 1980-1990s [Bloom, Canning, Sevilla 2003: 45]. But there is also a development scenario in which poor countries will not have time to take advantage of the opportunities provided by the demographic transition and reap the demographic dividend before the process of population aging begins.

\footnotetext{
Mikhail Denisenko (mdenissenko@hse.ru), NATIONAl ReSEARCH University Higher School of Economics, RUSSIA.
}

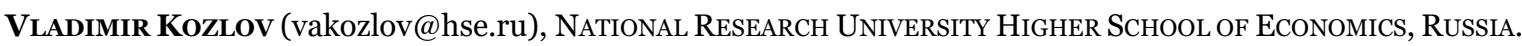

THE PAPER WAS PREPARED WITHIN THE FRAMEWORK OF THE NRU HSE APPLIED RESEARCH PROJECT TZ 148, “THE ENTRANCE OF RUSSIA INTO THE SYSTEM OF INTERNATIONAL COMPARISONS BASED ON NTA"

THE ORIGINAL ARTICLE IN RUSSIAN WAS PUBLISHED IN DEMOGRAPHIC REVIEW 2018, 5(4), 6-35.

DOI: 10.17323/DEMREVIEW.V5I4.8661 
Finding answers to demographic challenges means overcoming possible problems and conflicts, on the one hand, and realizing new opportunities for development, on the other. This is one of the main tasks of socio-economic policy. But to provide a firm foundation for its implementation it is necessary to correctly measure the effects of changes in the age structure of the population. The search for such indicators is one of the important tasks of economic and demographic research. However, the standard indicators of economic development adopted in the modern world apply mainly to the population as a whole, and do not reflect the contribution of certain age groups or generations to total production and consumption. While data on the age characteristics of consumption, income, and labor productivity in a number of countries are systematically collected and developed, the patterns of redistribution of income and resources between generations are unacceptably little known. Transfer systems, the functioning of which is mediated by the family institution, the state or the market, are themselves in a state of reform under the influence of the above-mentioned demographic changes.

Interest in assessing the effects of demographic changes in Russia has grown substantially in recent years. Many issues related to the organization of education, social welfare and healthcare, unresolved in the past, in the context of an increasing aging process threaten to escalate in the near future. In addition, interest in economic and demographic issues is increased by the continuing decline in the population at working ages, the accelerated increase in the proportion of people in the elderly population and, against this background, a likely increase in migration flows. Thus, the task of building adequate indicators reflecting the consequences of an aging population in Russia is extremely important in the very near future.

In this paper we will focus on two indicators that allow us to assess the impact of changes in the age structure of the population on economic development and present estimates of their effect on the Russian Federation. We are talking about the "life cycle deficit" indicator and the "effective economic support" indicator. Both of these indicators are developed in the framework of a new methodology for analyzing the redistribution of resources between generations - the system of national transfer (intergenerational) accounts. The article briefly discusses the basic provisions of the methodology for their construction. This part of the work is complemented by estimates of a number of indicators of the system of national transfer accounts for Russia for 2013. The final part presents estimates of the life cycle deficit and effective economic support, which reflect the impact of changes in the age structure of the Russian population on the country's economy in the near future. The article begins with a brief overview of the history of the inclusion of age structures in economic models.

\section{AGE POPULATION STRUCTURES IN ECONOMIC RESEARCH}

The numerous studies of the role of age composition and its changes in economic development have over time been unified into a discipline called Generational Economics. According to one definition, the economics of generations studies: 1) social institutions and economic mechanisms by which generations or age groups produce, consume, redistribute, and save resources; 2) economic flows between generations or age groups; 3) explicit and implicit contracts that manage intergenerational flows; and 4) incomes and consumption of separate generations and age groups [Lee, Mason 2011: 7]. The initial period in the history of research on this subject was 
distinguished by the fact that the work carried out by demographers remained largely unknown to economists, just as the work of scientists from former socialist countries was terra incognita for their Western counterparts.

The emergence of "Generational Economics" as a scientific field in Western literature is associated with the names of two Nobel laureates - Paul Samuelson and Franco Modigliani.

The macroeconomics of generations begins with the work of Samuelson and the overlapping generation model proposed by him [Barro, Sala-i-Martin 2004: 252]. In his study of the equilibrium rate of interest, P. Samuelson suggested that the life of a person is divided into two periods: working age (age 20 to 65 years) and retirement (age 65 and older). In the labor period, one part of a person's means goes to consumption (including childcare), and the other part to savings, so as to ensure consumption in old age. At older ages, a person consumes using his savings, as well as repaid loans once provided to younger generations. P. Samuelson called consumption of savings "time transfers" [Samuelson 1958: 471].

Subsequently, the model of intersecting generations became more complex, coming to include various forms of intergenerational transfers. As examples, we cite a few studies. In the next outstanding work after Samuelson's, Peter Diamond [Diamond 1965], another Nobel laureate, used this model to show the importance of national debt and a solidarity pension system for optimizing the level of consumption in society. In turn, R. Barro used the model of overlapping generations to express the hypothesis that intra-family transfers neutralize the redistributive effects of social transfers [Barro 1974]. In 1978 W. Arthur and J. McNicoll combined demographic models of the age structure with the model of Samuelson's intersecting generations, which allowed them to establish the significance of the growth rate and age composition of the population for savings and intergenerational transfers [Arthur, McNicoll 1978]. And in 1988 a collective monograph, "The Economics of Changes in the Age Structure in Developed Countries", was published, which touches upon various aspects of population aging: economic growth, cohort effects in earnings, impact on the labor market and the household sector, demographic features of pension systems, etc.[Lee, Arthur, Rodgers 1988]. We especially note the chapter prepared by R. Willis, where he tried to integrate microeconomic models of the life cycle of an individual and a household and of demographic behavior into the model of intersecting generations [Willis 1988].

The work of F. Modigliani and R. Bramberg marked the beginning of the microfoundations of the economics of generations. It formulated the concept of the economic life cycle and provided a foundation for the thesis on the relationship between consumption levels, savings and transfers between generations [Modigliani, Brumberg 1954]. Problems of intergenerational interactions seen through the prism of the concept of the life cycle have been considered in many studies. For example, M. Feldstein, relying on the economic life cycle model, was one of the first to suggest that public pension programs reduce the propensity to save [Feldstein 1974: 910]. L. Kotlikoff and L. Summers [Kotlikoff, Summers 1981], turning to the age profiles of earnings and consumption, established that intergenerational transfers, which are made, in their opinion, to support children or parents, are an important factor in saving and accumulating wealth. A somewhat different point of view was expressed by one of the authors of the concept of the economic life cycle, F. Modigliani, who argued that the desire to maintain one's level of consumption after retirement explains the accumulation of savings and capital in the United States [Modigliani 1988]. 
At the same time, it should be noted that as early as the first quarter of the twentieth century the outstanding Russian scientist A. Chayanov expressed and implemented the idea of building generational economic balances based on age profiles of production and consumption [Chayanov 1989]. Studying the budgets of peasant farms, he established a close relationship between the phases of the life cycle of a peasant family and the scale of its economic activity and consumption, revealing the contribution of particular generations to the development of peasant farms during certain phases of the life cycle.

In Europe, at the same time as in the United States, the process of analyzing the impact of demographic changes on economic development also went step by step. Thus, the ideas of the French economic and demographic school regarding intergenerational interactions and the consequences of population aging in the 1960s were summarized in the work of A. Sauvy, "General Population Theory" [Sauvy 1977]. It is necessary also to note the works of the Hungarian demographer E. Valkovich (1971), unique for their time (1960-1970s). To assess the influence of age structures, he proposed the method of economic age pyramids. According to the results of surveys, he determined the age profiles of income and consumption in Hungary and, based on them, periods of shortage or excess of resources at certain stages of the life cycle. Age pyramids or structures were calculated by multiplying the age indicators obtained by the population of the respective age groups. A comparison of economic pyramids over a number of years made it possible to estimate the effect of the changes in the age structure for aggregate indicators of production, consumption, savings, etc.

In the 1970-1980s, the Australian demographer J. Caldwell, based on the ideas of A. Chayanov, developed the theory of the demographic transition, a key element of which was the analysis of the directions of wealth flows between generations [Caldwell 1982]. Intergenerational relations in a traditional society took shape in favor of the older ages, since the system of kinship support was directed towards them, and economic activity began in childhood. According to the results of a number of studies by J. Caldwell and his followers, the economic value of children due to the "net flow of benefits" from them for parents was high. The transfer system for the redistribution of resources of a traditional society, which developed in conditions of high mortality, ensured high fertility.

In the USSR in 1986 a paper by E. Andreev and L. Darsky was published on economic and demographic processes in real generations [Andreev, Darsky 1986]. Based on the model of a stable population, as well as on some ideas of B. Urlanis [Urlanis 1971; 1976], they estimated the volume of goods produced and consumed by different generations, depending on the rate of increase in labor productivity, the level of mortality and the rate of population growth. Andreev and Darsky showed that a situation of negative economic balance between generations is possible, i.e. an excess of consumption over the volume of produced goods. This is due to the fact that the period of labor activity in the 1970-1980s decreased due to the lengthening of the period of education and the development of the pension system. They agreed with Urlanis that the systematic negative balance of generations is not necessarily associated with a decrease in national wealth. This balance can be covered at the expense of other generations, including younger ones with higher productivity. At the same time, the balance of the hypothetical generation remains positive. The concept of balance here actually corresponds to the concept of a life cycle deficit adopted in foreign literature. 
The results of numerous and long-term studies ultimately led scientists to conclude that the task of assessing the effects of demographic changes on economics and public policy should be addressed through balance equations for the redistribution of resources between generations (age groups), combining analytical methods of demography and economic theory. Work on creating intergenerational balances within the framework of the system of national accounts began in the 1980s. The credit for creating a modern system belongs to two Americans - the demographer Ronald Lee and the economist Andrew Mason [D'Albis, Moosa 2015]. Thus, as early as 1980 R. Lee summed up the work of researchers over a twenty-year period. There he also made one of the first attempts to assess the effect of changes in the age structure through intergenerational transfers on economic growth [Lee 1980]. E. Maiso, in his 1988 paper, showed the value of an intergenerational approach to studying savings [Mason 1988]. In 1994, R. Lee, analyzing the consequences of population aging, attempted to combine models of population reproduction with economic models and research topics, including models of overlapping generations, optimal population growth, savings and the life cycle, generational accounting (to be discussed below), the study of the population's reaction to the introduction of public transfer programs, etc. [Lee 1994].

In their subsequent work, R. Lee and E. Mason developed a methodology for constructing and analyzing balances (accounts) of economic flows, taking into account the age composition of the population. They expressed the idea of building age balances of time budgets. Subsequently, this idea was implemented as part of a research project, "National Transfer Accounts". The age profiles of consumption and income were later used to build models of capital accumulation and the redistribution of wealth and the development of the system. Using age profiles of taxes and benefits, R. Lee and S. Tuljapurkar [Lee, Tuljapurkar 2000] built a long-term forecast of financial development of the US social security system in the context of demographic aging, and R. Lee and T. Miller estimated the long-term fiscal implications of immigration for the US [Lee, Miller 2000]. A group of researchers (A. Bomier, R. Lee, and others) determined which of the generations from 1850 to 2090 born in the United States are winners and which losers as a result of the redistribution of resources through a channel of public intergenerational transfers [Bommier et al. 2010].

Wide scientific and public interest in assessing the effects of demographic changes, as well as the results of numerous scientific studies led to the fact that in 2002, under the scientific leadership of R. Lee and A. Mason, an international project was launched to develop a methodology for constructing a system of national intergenerational (transfer) accounts and their application. The first participants in the project, in addition to the developed countries (USA, France, Japan), were developing countries (Brazil, Indonesia, Taiwan, Chile) which had experienced rapid changes in the fertility, mortality and age structure of the population. Initially, the project was supported by the US National Institute of Aging, but a few years later the United Nations Population Fund, then the European Commission, the Center for the Development of International Studies of Canada and the Population Division of the UN Secretariat joined the project. Currently, 94 countries are participating in the project, including Russia ${ }^{1}$.

\footnotetext{
${ }^{1}$ Russia is represented by the National Research University Higher School of Economics
} 
In the late 1990s and early 2000s the American demographer David Bloom and his colleagues showed that the "miracle" of the rapid economic growth of Asian countries (China, Thailand, Taiwan, South Korea) is largely due to changes in the age structure of the population [Bloom, Williamson 1998; Bloom, Canning, Malaney 2000; Bloom, Canning, Sevilla 2003]. As a result of the rapid decline in fertility, the proportion of people in working age has increased and the demographic burden has decreased. The resulting gain was called a demographic dividend. Since then, "demographic dividend" has become one of the central concepts in economic and demographic studies [Lee, Mason 2006]. New approaches to its assessment, as well as to the assessment of support ratios taking into account the age peculiarities of income and consumption, were developed within the framework of the system of national transfer accounts [Prskawetz, Sambt 2014; Mason et al. 2017].

Note that in addition to the national transfer accounts addressed by the authors of this article, there are other methods for assessing the redistribution of resources between generations. For example, in the early 1990s the American economists and demographers L. Kotlikoff, A. Auerbach, and J. Gokhale proposed a method, called Generational Accounting, to evaluate the effects of demographic aging and the financial efficiency of existing government programs that redistribute income between generations (primarily pension programs) [Kotlikoff 1992; Auerbach, Gokhale, Kotlikoff 1994]. In 2013, at the E.T. Gaidar Institute of Economic Policy, an economic and demographic study of the current and prospective state of public finances in Russia, "Assessment of the budget gap in the Russian Federation", was conducted with the participation of L. Kotlikoff ${ }^{2}$. According to experts, current fiscal policy cannot ensure the sustainability of the budget system over the long term, largely due to the aging of the population, which will increase the costs of pensions and medical services. As a result, the budget gap, according to which the stability of state finances was assessed, in Russia by 2015 should have increased to $11.8-14.1 \%$. But the problem was not only in the aging of the population, but also in the likely decline in budget revenues from the export of hydrocarbons (the impact of which on the budget gap was about 2 times greater than the demographic one).

\section{INTERGENERATIONAL ACCOUNTS}

An economic system can be represented as flows of wealth between people and various institutions, among which an important place is occupied by flows between generations or intergenerational transfers. However, in the main system for describing and analyzing macroeconomic processes in the countries of the world - the system of national accounts (SNA) ${ }^{3}$

\footnotetext{
${ }^{2}$ Project website: URL: http://www.iep.ru/ru/ocenka-byudzhetnogo-razryva-v-rf-russia-s-fiscal-gap.html. The main results were published later in the article [Goryunov et al. 2015].

${ }^{3}$ The system of national accounts arose about 50 years ago in the most economically developed countries due to the need for information necessary for analyzing the state of the economy, formulating economic policies and taking measures to regulate a market economy. Conceptually, this system is integrated with the balance of payments and a number of other sections of macroeconomic statistics. The essence of the SNA is the formation of summary indicators of economic development at various stages of the reproduction process and the mutual linking of these indicators among themselves. Each stage of reproduction (production stage, primary distribution of income, secondary distribution of income, use for final consumption and accumulation, etc.) corresponds to a special account or group of accounts. The national accounts system reflects flow accounts, i.e. the movement of flows of goods,
} 
- the redistribution of resources between age groups (generations) is not reflected. Thus, this system is in no way linked to the epoch-making demographic changes occurring at the turn of the twentieth and twenty-first centuries in both developed (with demographic aging) and developing (with declining fertility) countries of the world. The authors of the idea of linking the SNA with demographic processes are the already mentioned economist Andrew Mason and the demographer Ronald Lee. Finally, they developed the concept of building National Transfer (Intergenerational) Accounts (NTA), which in their full form represent a systemic and comprehensive display of existing economic flows as flows between age groups [Lee, Mason 2011; United Nations 2013].

Externally, the system of national transfer accounts in full form represents the distribution of a number of national accounts indicators by one-year age groups. But there are differences between the SNS and NTA systems. In particular, the unit of analysis in intergenerational accounts is the individual, not the household. Although household consumption is carried out jointly, according to the authors of NTA in most cases consumption is individual. At the same time, there are economic flows that cannot be directly distributed by age groups: a) flows between institutions, for example, between corporations and the state; b) a series of flows of public goods, for example, defense expenditures, the state apparatus, the judicial system; c) many flows which in statistics are not linked with an individual, but with households. In practice, when building national transfer accounts for the distribution of these flows between age groups, various assumptions and/or models are used.

Social institutions in the concept of national transfer accounts act exclusively as intermediaries for exchanges between age groups. For example, a firm's profit is viewed through the prism of the age of its owner, government transfers through the age of taxpayers and recipients of various kinds of benefits and privileges. In total, there are three groups of institutions: 1) private institutions: corporations, households, non-profit organizations; 2) public or state institutions; and 3 ) the rest of the world, which is associated with the inflow or outflow of wealth from abroad.

The system of transfer accounts uses the categories "labor income" and "income from assets", which are not defined in the system of national accounts, but are defined on their basis. According to the methodology for building transfer accounts, labor income, capital income and consumption are estimated before taxes and subsidies on products and production are paid.

According to the methodology of building national transfer accounts, labor income is a source of resources for consumption. In contrast to national accounts, all other forms of individual incomes (rent, interest, pensions, etc.) fall into the category of reallocation, i.e. are the result of the redistribution of resources to meet current or future consumption. Labor income, in turn, has two components: the remuneration of employees (including various kinds of bonuses from the employer - for example, the cost of the social package) and income from self-employment. Income from self-employment is calculated as two thirds of the mixed income in national accounts.

The central feature of the concept of national transfer accounts is the economic life cycle, which primarily reflects the characteristics of age consumption and income models. At certain stages of the life cycle (in childhood and adolescence, in middle and older ages), the material needs

services and income through all stages (from production to use), as well as changes in non-financial assets and financial assets and liabilities (See: [System of National Accounts 2012]). 
of a person and the possibilities of their satisfaction created by his work may not coincide. There thus arises a shortage of resources for consumption at the stages of childhood and old age and a surplus at middle ages. This deficit is covered through the redistribution (reallocation) of resources from age groups in which there is an excess of them to age groups in which there is a shortage, in the form of intergenerational transfers and asset-based reallocations [United Nations 2013: 26, 31]. Redistribution mechanisms and corresponding resource flows, depending on the institutions between which they are implemented, are divided into private and public.

Intergenerational transfers are material resources or services passed on gratis from the older generation to the younger (downstream transfers) and from the younger generation to the older generation (upstream transfers). The category of "transfers" in the system of national transfer accounts is interpreted very broadly. It includes all gratuitous flows of goods between individuals, including social payments and services from the state, tax payments and deductions for social insurance, transfers between households and within households. It should be noted that there are no analogues of the last two types of transfers in the system of national accounts, and they are evaluated using other sources of information. Accounting for transfers within households and methods for their evaluation are one of the important scientific and practical innovations that have been justified within the framework of the concept of national transfer accounts.

The age-based redistribution of assets is realized in time in the form of accumulation of savings and their spending, as well as income from assets as a person transitions to the older age group. Thus, savings are made throughout one's working life, and spent after retirement. In his youth, a person receives loans for education, which he pays back after graduation. Buying bonds, stocks, durable goods, housing, land, insurance, consumer loans, etc. are all examples of assetbased redistribution.

Economic flows in the NTA system, in addition to being divided into public and private, are also divided by the main goals of consumption and the purpose of transfers: education, health care, government pensions, etc.

In effect, the system of national intergenerational accounts is designed to answer the question of how the deficit arising at different stages of the life cycle is covered. The economic life cycle is expressed by the following balance equation linking the main flows of the system of intergenerational accounts (formula 1):

where:

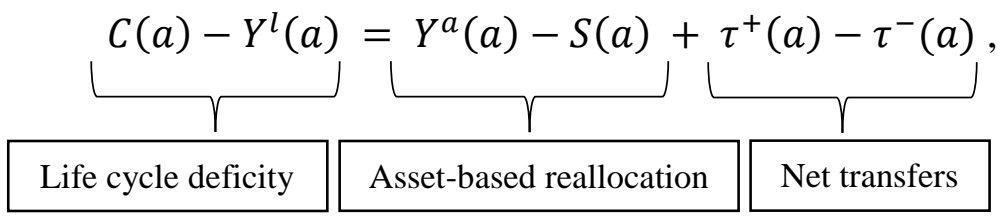

$a-$ is age;

$C(a)$ - is consumption;

$Y^{l}(a)$ - is labor income;

$Y^{a}(a)$ - is income from assets;
$S(a)$ - is savings;

$\tau^{+}(a)$ - is received transfers;

$\tau^{-}(a)$ - is transmitted transfers.

A positive value of this equation indicates a shortage of resources at a given age, while a negative one indicates their excess or surplus. It should be noted that estimates of national transfer 
accounts are constructed for individual calendar years, and age distributions of economic indicators are interpreted in terms of conditional generations. But recently, as more information accumulates, attempts are being made to build transfer accounts for real generations [Temple, Rice, McDonald 2017].

\section{AgGREGATED TRANSFER ACCOUNTS}

The construction of national transfer accounts begins with the collection of statistical information in three areas:

1) the number of age groups of the population. If transfer accounts are built for individual sociodemographic groups (sex, education, urban-rural, migrants, etc.), then in such cases an agerelated composition of these groups is necessary;

2) national accounts containing basic information on economic flows which will be distributed by age. Based on the national accounts indicators, aggregated indicators (macrocontrollers) of income, consumption, transfers, income from assets and savings of intergenerational accounts are calculated;

3) nationally representative household surveys and administrative sources of information (tax services, treasury, ministry of education, etc.). According to data from these sources, age profiles of economic indicators are estimated (per capita) for distribution by age groups (generations) of aggregated indicators and the final construction of transfer accounts.

Based on the relevant data sources, the authors of the article have attempted to build national transfer accounts and assess the life cycle deficit in Russia for 2013. This year was not chosen randomly to start work on creating the NTA system: it was the last year before the financial and economic crisis that began at the end of 2014 and the introduction of a regime of sanctions against Russia by Western countries. Also taken into account was the fact that since 2011 Rosstat had switched to a modernized methodology for the construction of national accounts [System of National Accounts 2012; National Accounts of Russia 2013].

At the first stage, the values of aggregate indicators (macrocontrollers) of resource flows in the system of national transfer accounts ${ }^{4}$ were estimated. The results of the evaluation are presented in table 1. By analogy with the system of national accounts and depending on the institutions involved, these results are presented in the form of the following accounts:

- life cycle account;

- account of public redistribution of benefits between age groups;

- account of private redistribution of benefits between age groups ${ }^{5}$.

This article focuses on the life cycle account. Its components (age profiles of income and consumption) make it possible to proceed to refined estimates of support ratios and a demographic

\footnotetext{
${ }^{4}$ A detailed methodology for the transition from SNA to NTA is set out in the Guidelines for the construction and analysis of national transfer accounts [United Nations 2013].

${ }^{5}$ Table 1 does not provide estimates of the volume of transfers between and within households that are not counted in the SNA. They are made according to the results of surveys. Currently, work is underway to refine the model of these transfer flows.
} 
dividend reflecting the impact of changes in the age structure of the Russian population on its economic development.

\section{CONSTRUCTION OF AGE PROFILES}

Next, the main task becomes the distribution of aggregated indicators of flows by generations, i.e. obtaining so-called age profiles of macro indicators of the system of national transfer accounts. Profiles are built by one-year age groups. This problem is solved in two steps.

Table 1. Aggregated indicators (macrocontrollers) of the system of national transfer accounts of Russia in 2013, billion rubles.

\begin{tabular}{|c|c|c|c|c|c|}
\hline \multicolumn{2}{|c|}{$\begin{array}{l}\text { Deficit account }(+) / \text { surplus }(-) \\
\text { of the life cycle }\end{array}$} & \multicolumn{2}{|c|}{$\begin{array}{c}\text { Public resources } \\
\text { redistribution account }\end{array}$} & \multicolumn{2}{|c|}{$\begin{array}{l}\text { Private resources } \\
\text { redistribution account }\end{array}$} \\
\hline name & volume & name & volume & name & volume \\
\hline Life cycle deficit & 3473 & Public redistribution & 1224 & Private redistribution & 2249 \\
\hline Consumption & 43010 & Net public transfers: & 245 & Net private transfers: & -543 \\
\hline Public consumption: & 13552 & $\begin{array}{l}\text { for education: } \\
\text { inflow }\end{array}$ & 1817 & $\begin{array}{l}\text { between households: } \\
\text { inflow }\end{array}$ & Not in SNA \\
\hline educational services & 1817 & $\begin{array}{l}\text { for education: } \\
\text { inflow }\end{array}$ & 1817 & $\begin{array}{l}\text { between households: } \\
\text { inflow }\end{array}$ & Not in SNA \\
\hline healthcare services & 2050 & $\begin{array}{l}\text { for education: } \\
\text { outflow }\end{array}$ & 2051 & $\begin{array}{l}\text { within households: } \\
\text { inflow }\end{array}$ & Not in SNA \\
\hline other & 9684 & $\begin{array}{l}\text { for healthcare: } \\
\text { inflow }\end{array}$ & 2051 & $\begin{array}{l}\text { within households: } \\
\text { outflow }\end{array}$ & Not in SNA \\
\hline Private consumption: & 29458 & $\begin{array}{l}\text { for pensions: } \\
\text { inflow }\end{array}$ & 5250 & $\begin{array}{l}\text { Redistribution based on } \\
\text { assets: }\end{array}$ & 2793 \\
\hline educational services & 244 & $\begin{array}{l}\text { for pensions: } \\
\text { outflow }\end{array}$ & 5250 & net income from capital & 10946 \\
\hline healthcare services & 1173 & $\begin{array}{l}\text { others in kind: } \\
\text { inflow }\end{array}$ & 9684 & $\begin{array}{l}\text { imputed earnings of } \\
\text { homeowners }\end{array}$ & 5287 \\
\hline other & 28041 & $\begin{array}{l}\text { others in kind: } \\
\text { outflow }\end{array}$ & 9684 & $\begin{array}{l}\text { net income from } \\
\text { property }\end{array}$ & -5107 \\
\hline Labor income: & 39536 & $\begin{array}{l}\text { others in cash: } \\
\text { outflow }\end{array}$ & 3595 & net private savings & 8333 \\
\hline $\begin{array}{l}\text { remuneration of } \\
\text { employees }\end{array}$ & 11 & $\begin{array}{l}\text { others in cash: } \\
\text { inflow }\end{array}$ & 3350 & & \\
\hline $\begin{array}{l}\text { self-employment } \\
\text { income }\end{array}$ & 5725 & $\begin{array}{l}\text { Redistribution in the } \\
\text { form of assets }\end{array}$ & 979 & & \\
\hline & & $\begin{array}{l}\text { net income from } \\
\text { capital }\end{array}$ & -51 & & \\
\hline & & $\begin{array}{l}\text { net income from } \\
\text { property }\end{array}$ & 2981 & & \\
\hline & & net public savings & 1951 & & \\
\hline
\end{tabular}

Source: Built by the authors together with the staff of the Institute for Development Center at the HSE University A. Nazarova A. and A. V. Chernyavsky.

The first is to construct, using data from surveys or administrative sources containing information about the age of respondents or users of services, primary age profiles reflecting the level of per capita consumption, labor income, transfers, or savings. As noted above, in surveys much of the information is tied not to individuals, but to the households in which they live. In this regard, the problem arises of the transition from household estimates to individual estimates, since the unit of observation in intergenerational accounts is the individual. To solve this problem, two approaches are often used: 1) household members are assigned consumer weights, or all resources 
are attributed to the household head (for example, taxes or rent income); 2) statistical methods (regressions) are used to distribute a particular value among members of households.

To construct the primary age profiles the following data sources were used:

- household surveys (for obtaining income profiles, private consumption, including health care services): Russian Monitoring of Economic Status and Health of the Higher School of Economics National Research University (HSE); Survey of Incomes and Participation in Rosstat Social Programs;

- HSE survey in the framework of the monitoring of the economics of education, "Surveys in educational organizations implementing programs of various levels of education" (to obtain profiles of private consumption of education services);

- administrative data (for obtaining age profiles of users of public health and education services): the Federal Treasury, the Mandatory Health Insurance Fund, the Ministry of Education.

To assess public consumption differing from education and health care by the lack of a clear age component (defense, maintenance of the state apparatus, protection of public order, etc.), its uniform distribution per person by age groups was assumed. A similar approach was used when building transfer accounts, for example, in the USA.

The second step is to convert the primary profiles into a profile corresponding to the macrocontrollers obtained earlier (an aggregate figure derived from national accounts). A new, secondary profile is a direct part of national transfer accounts. This problem is solved by introducing a special coefficient of proportionality $\Theta$, which "adjusts" the values of the primary profiles to the values of the macrocontrollers. The proportionality coefficient is calculated as the ratio of the size of the macrocontroller to the aggregated estimate of the value of the same indicator, calculated as the sum of the products of the number of age groups by the corresponding value of the indicator per capita from the primary profile (formula 2):

$$
\Theta=\frac{X}{\sum x(a) N(a)}
$$

where:

$a-$ is age;

$N(a)$ - is the population of $a$;

$X-$ is the macro controller;

$x(a)$ - is the age-specific primary profile of the indicator $X$ (per capita).

Multiplying the proportionality coefficient (2) by the indicators of the primary age profile, we obtain the age profile of national transfer accounts (NTA) per capita (3) for a given value of the aggregate indicators of income, consumption or redistribution of benefits. By multiplying the per capita indicators thus found by the population size, it is possible to obtain the distribution of aggregated income or consumption across all age groups (4): 


$$
\begin{aligned}
& \bar{x}(\mathrm{a})=\theta x(a), \\
& \bar{X}(\mathrm{a})=\bar{x}(\mathrm{a}) \mathrm{N}(\mathrm{a}),
\end{aligned}
$$

where:

$\bar{X}($ a) - is the NTA age profile (per capita);

$\bar{X}(a)$ - is the aggregated NTA profile at age $a$.

\section{THE ECONOMIC LIFE CYCLE IN RUSSIA}

Indicators of the economic life cycle can be studied at the micro level (individual behavior) and aggregated at the macro level. At the macro level, the most important factor determining the characteristics of the life cycle is the age structure of the population. Changes in the age structure lead to an increase in the number of a certain age group of dependents or workers. Depending on how the age structure changes, the population produces or consumes more or less resources.

The constructed age models (profiles) of labor income, consumption and life cycle deficit for Russia are shown in Figure 1. The aggregated indicators of labor income and consumption reflect the characteristics of the age structure of the population.

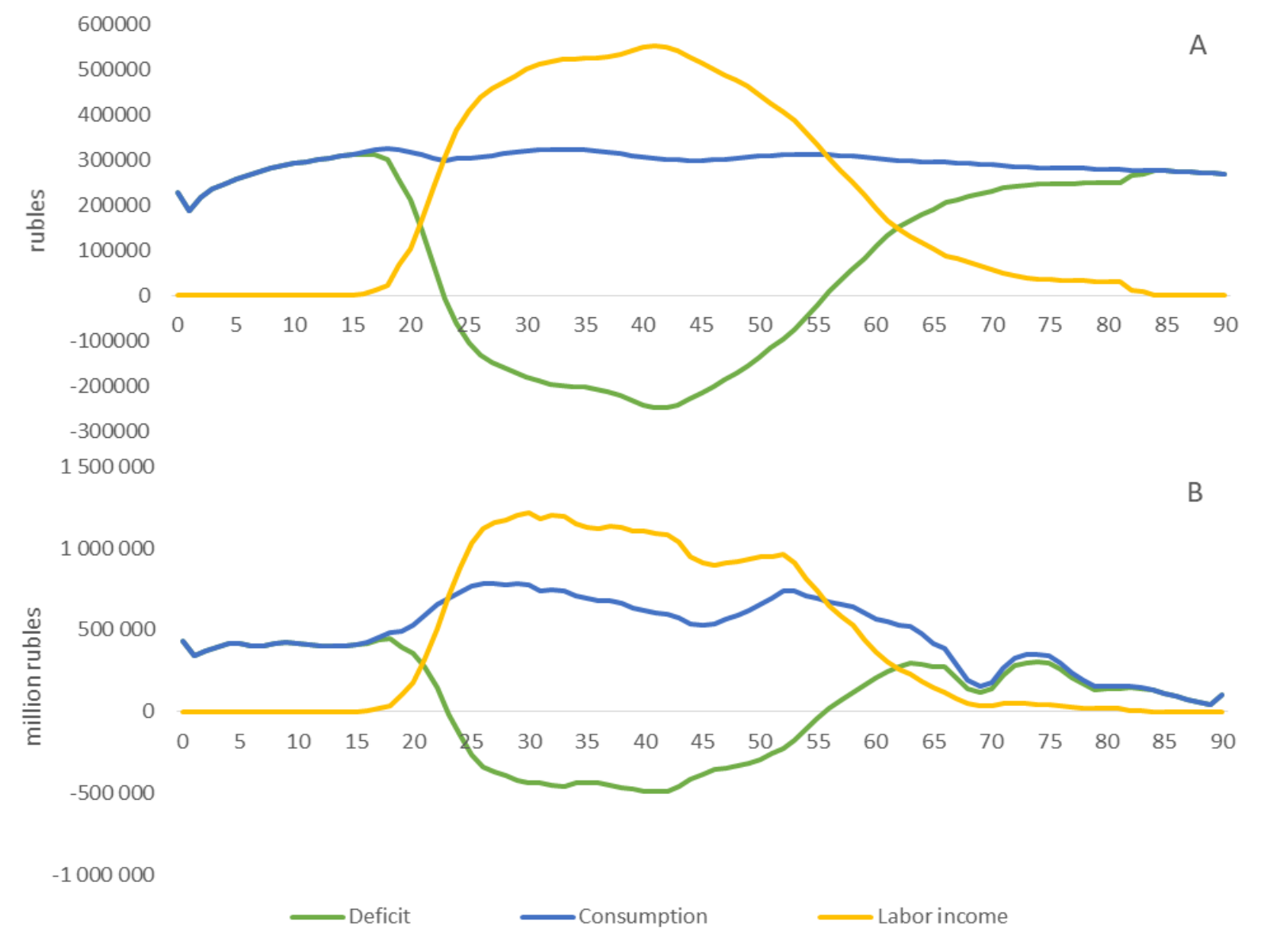

Figure 1. The economic life cycle in Russia: per capita (A), aggregated (B), 2013

Source: Authors' calculations. 
Aggregate and per capita estimates of labor income and consumption make it possible to estimate the life cycle deficit and its features in certain periods of people's lives (Figure 1). For the Russian population, the "deficit-free period" begins at age 23 and lasts up to age 56. In most developed countries (Table 2), due to a longer period of study the "deficit-free" period begins later. In developing countries, it starts later due to the lack of permanent sources of income and the nature of relationships with heads of households. A later retirement in developed countries implies a later end to a "deficit-free" period compared to Russia. In most developing countries where there is no pension system, the end time of a "deficit-free" period is determined by the physiological abilities of a person - the average age up to which he can work.

Table 3 presents a brief account of the economic life cycle of the national transfer accounts of Russia. The high level of public consumption in relation to the private in children's ages draws attention. In total, the life cycle deficit in Russia in 2013 amounted to 3,473 billion rubles, or about $4.7 \%$ of GDP.

Table 2. Age limits of the "non-deficit" stage of the life cycle in different countries of the world

\begin{tabular}{l|c|c}
\hline Country (year of assessment) & $\begin{array}{c}\text { Lower limit, } \\
\text { years }\end{array}$ & Upper limit, years \\
\hline USA (2003) & 25 & 60 \\
Nigeria (2004) & 31 & 62 \\
Germany (2010) & 27 & 57 \\
Mexico (2003) & 32 & 49 \\
S. Korea (2000) & 23 & 56 \\
S. Korea (2010) & 27 & 55 \\
Russia (2013) & 23 & 55 \\
\hline
\end{tabular}

Source: NTA Database - URL: http://www.ntaccounts.org (appeal date: 12.22.2018), for Russia - the authors' calculations.

One of the important advantages of NTA is the opening up of opportunities for complex cross-country comparisons of income, consumption and redistribution of resources. To do this, the relevant indicators must be normalized. So, for the purposes of international comparisons, the age characteristics of the labor income of the population of Russia and the compared countries (Figure 2) were normalized by dividing by the average income in ages from 30 to 49 years inclusive. The results of these comparisons show that, in contrast to the developed countries, as well as some developing countries, the income peak in Russia is about 40 years old. In countries such as the USA or Germany, this peak is observed at pre-retirement ages. The age model for obtaining labor income in Russia in 2013 resembles the model for South Korea in 2003 (Figure 2).

As regards private consumption, with the exception of health care and education services it was also evaluated on the basis of the above-mentioned surveys. 


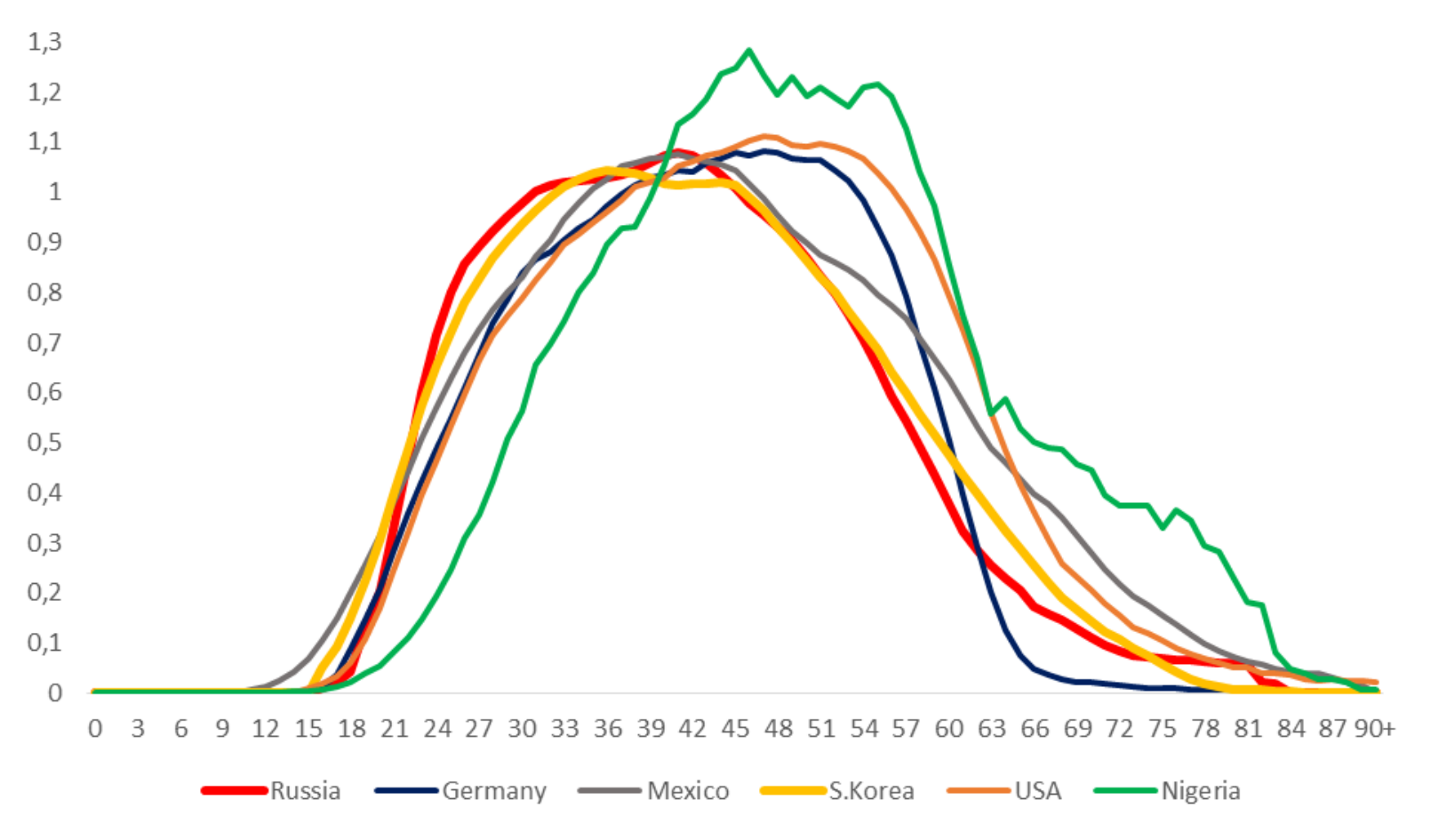

Figure 2. Normalized income indicators (average income $[30-49$ years] $=1$ ) per capita for some countries of the world, 2003-2013

Source: NTA Database - URL: http://www.ntaccounts.org (appeal date: 12.22.2018), for Russia - the authors' calculations.

The age profiles of consumption per capita for some countries of the world are shown in Figure 3. The highest level of consumption in Russia falls on the younger working ages (Figure 3 and Table 2), and in developed countries on older, non-working ages, largely due to the high costs of health services (both private and public). The age model of consumption in Russia, as in the case of labor income, is similar to the South Korean model. But the reasons for this similarity must also be clarified.

Table 3. Life cycle deficit, income and consumption characteristics by integrated age groups, Russia, 2013

\begin{tabular}{l|r|r|r|r|r|r|r|r}
\hline \multirow{2}{*}{ Categories } & \multicolumn{3}{|c|}{ Aggregates for year, billion rubles } & \multicolumn{4}{c}{ Per capital for year, rubles } \\
\cline { 2 - 8 } & \multicolumn{1}{|c|}{ All } & 0-19 years & $\begin{array}{c}20-64 \\
\text { years }\end{array}$ & $\begin{array}{c}65 \text { years } \\
\text { and older }\end{array}$ & All & 0-19 years & $\begin{array}{c}20-64 \\
\text { years }\end{array}$ & $\begin{array}{c}65 \text { years } \\
\text { and older }\end{array}$ \\
\hline Life cycle deficit & 3473 & 8303 & -9282 & 4452 & 24203 & 275335 & -98063 & 238047 \\
Consumption & 43010 & 8320 & 29355 & 5335 & 299706 & 275898 & 310146 & 285255 \\
Public consumption & 13552 & 3997 & 7900 & 1656 & 94434 & 132538 & 83463 & 88520 \\
$\quad$ Education & 1817 & 1457 & 360 & 0 & 12662 & 48331 & 3799 & 8 \\
$\quad$ Healthcare & 2050 & 504 & 1153 & 393 & 14288 & 16724 & 12180 & 21028 \\
Other & 9684 & 2035 & 6387 & 1262 & 67484 & 67484 & 67484 & 67484 \\
Private consumption & 29458 & 4323 & 21455 & 3680 & 205271 & 143360 & 226683 & 196735 \\
$\quad$ Education & 244 & 218 & 25 & 0 & 1700 & 7245 & 268 & 0 \\
$\quad$ Healthcare & 1173 & 142 & 745 & 287 & 8174 & 4702 & 7867 & 15321 \\
$\quad$ Other & 28041 & 3963 & 20685 & 3393 & 195398 & 131413 & 218547 & 181415 \\
Labor income & 39536 & 157 & 38541 & 838 & 275502 & 5219 & 407201 & 44807 \\
Earnings & 33811 & 149 & 32871 & 792 & 235606 & 4930 & 347291 & 42331 \\
Self-employment income & 5725 & 9 & 5670 & 46 & 39896 & 289 & 59910 & 2476 \\
\hline
\end{tabular}




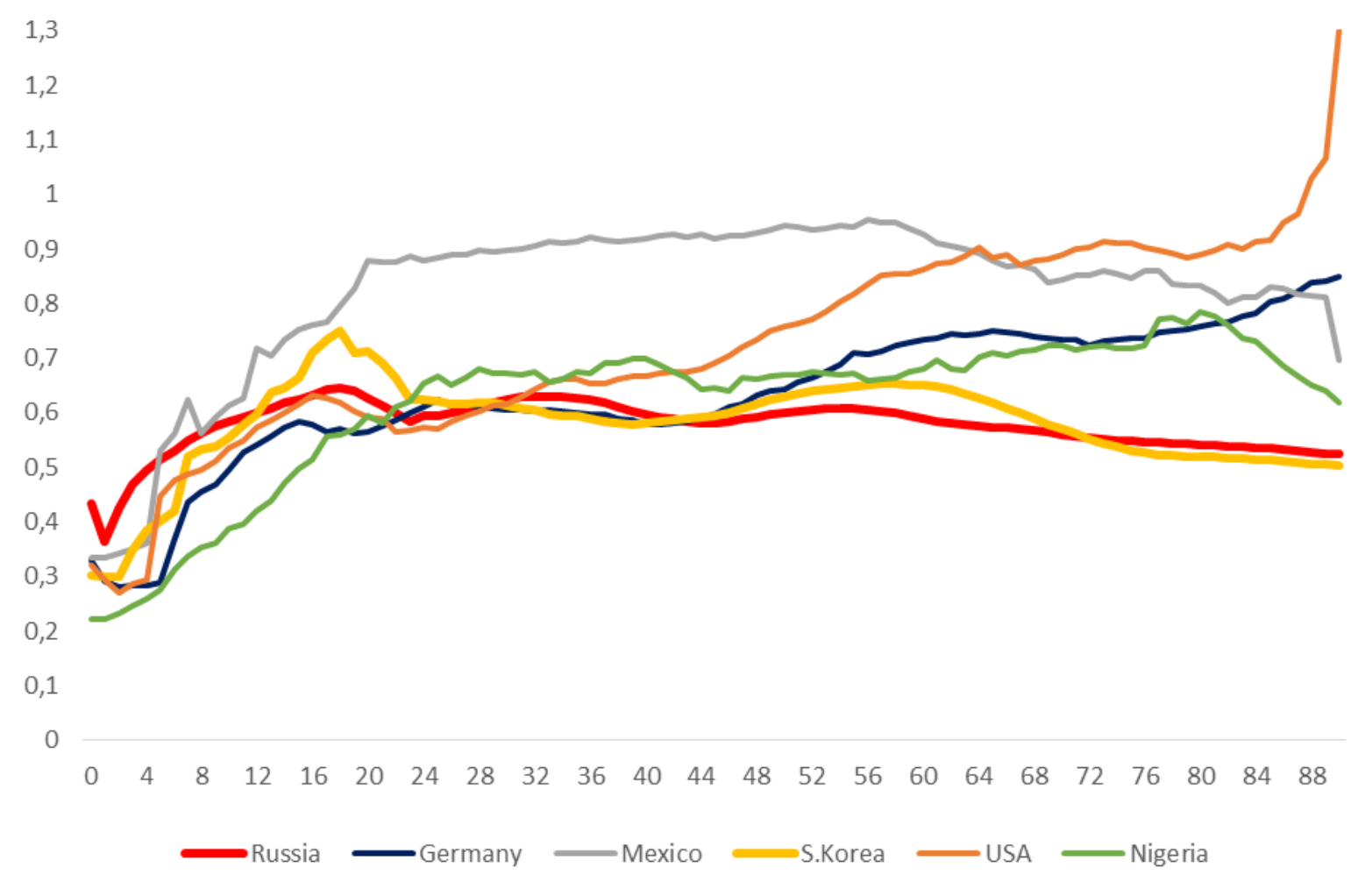

Figure 3. Normalized consumption indicators per capita (average income [30-49 years] = 1) for some countries of the world, 2003-2013

Source: NTA Database - URL: http://www.ntaccounts.org (appeal date: 12.22.2018), for Russia - the authors' calculations.

\section{THE LIFE CYCLE DEFICIT IN RUSSIA UNTIL 2050 IN THE CONDITIONS OF DEMOGRAPHIC CHANGES}

An increase in the life cycle deficit, ceteris paribus, means that total consumption increasingly exceeds total labor income. Consumption of young and older generations is provided by increasing amounts of transfers or at the expense of existing assets. In particular, the source of these revenues may be private savings, receipts from the state budget or external borrowings. Reducing the deficit suggests otherwise: more resources in the form of social transfers can be directed to education and health care, i.e. to investment in human capital. To assess changes in the life cycle deficit taking into account the "demographic factor", its relation to GDP was used. To estimate the future trends, it was assumed that the life cycle deficit changes under the influence of changes in the age structure. All economic parameters (labor productivity, economic structure, distribution relations, age profiles of income and consumption, etc.) were assumed to remain unchanged. The only exception made was for the retirement age, scheduled to be raised starting from 2019 (in this case, allowance was made for a change in the age profile of income). 
The life cycle deficit in relation to GDP was estimated for the period from 2017 to $2050^{6}$. In 2017, this ratio was $4.5 \%$. To assess the impact of changes in the age structure of Russia on the life cycle deficit we turned to three scenarios of demographic forecast made at the Institute of Demography in 2017. The following scenarios are included in the so-called "low" version of the forecast:

1) a slow decline in mortality compared with the level of 2017;

2) a decrease in the total fertility rate to 1.57 ;

3) a small migration increase (in 2050, about 100 thousand people per year).

Under such scenarios, in the period from 2018 to 2050 the proportion of the population aged 65 years and older increases from 14.5 to $23 \%$, the proportion of children under 15 years old decreases from 18 to $15 \%$, and the proportion of people in the working age range 15-64 years is reduced from 67.5 to $62 \%$. According to the second, "medium" scenario, fertility rises to two births per woman, life expectancy at birth increases by more than 5 years and the net migration on average per year is 300 thousand people. Under such a scenario, the proportion of persons at older ages increases from 14.5 to $22.5 \%$, the proportion of children up to 15 years old stays at $18 \%$, and the proportion of the population at working ages drops to 59.5\%. According to the high scenario of the forecast, the total fertility rate increases to a level that ensures simple reproduction of the population (2.1 births per woman), life expectancy increases by 7 years and the annual net migration increases by 2050 from 300 thousand to almost 500 thousand persons. As a result, the proportion of the child population approaches $17.7 \%$, the proportion of persons at older ages is $23.8 \%$, and the proportion of persons at working age is $58.5 \%$.

The life cycle deficit was assessed under the condition that the age profiles of consumption and labor income were consistent. In assessing GDP, as mentioned above, it was assumed that labor productivity is constant. Therefore, GDP changed only as a result of changes in the number of the employed population (estimates were made in constant prices). The forecast of the employed population was also carried out at the Institute of Demography in 2017. As a result, GDP (at constant prices) under the low scenario of the demographic forecast will decrease by $24.5 \%$, under the medium scenario by $18.8 \%$, and under the high scenario by $15.9 \%$.

The results of life cycle deficit assessments in relation to GDP are presented in Table 4. As can be seen, the deficit increases to the greatest extent in the case of a high (optimistic) version of the demographic forecast, and to a lesser extent, on the contrary, as a result of a low or worst scenario of demographic development. This is not surprising, since according to the low scenario of the forecast the share of persons in working age is the highest of the three scenarios of the demographic forecast. Due to the low birth rate in the population, the proportion of childhood ages decreases and relatively high mortality inhibits the growth of the number of people in retirement ages. In other cases, due to higher fertility and lower mortality the proportion of dependent groups increases. The paradox of the situation is that in pursuing an active demographic policy the country seems to be increasing the life cycle deficit: more private, public and, possibly, external resources

\footnotetext{
${ }^{6}$ Assessment of the life cycle deficit for 2017 was carried out by members of the Institute for Development Center at HSE A.G. Nazarova and A.V. Chernyavsky in the framework of the project TZ-148 of the Center for National Financial Institutions of the National Research University Higher School of Economics, "Inclusion of Russia in the international comparison system for national generation accounts".
} 
are needed to cover it. But it should be remembered that, in the case of the low scenario of a demographic forecast, GDP (other things being equal, excluding changes in productivity and investment in capital) will decrease by a quarter, while under the high scenario it will be only $15 \%$.

Table 4. The ratio of the life cycle deficit to GDP, \%

\begin{tabular}{|c|c|c|c|c|c|}
\hline Demographic scenario & Economic scenario & 2017 & 2025 & 2035 & 2050 \\
\hline Low & Unchanged productivity & \multirow{4}{*}{4,5} & 9,4 & 11,7 & 13,5 \\
\hline Medium & Unchanged productivity & & 10,0 & 13,7 & 16,5 \\
\hline High & Unchanged productivity & & 10,1 & 13,9 & 18,0 \\
\hline Medium & Increased retirement age & & 3,8 & 5,2 & 7,5 \\
\hline
\end{tabular}

Source: authors' calculations.

How to resolve this paradox? The first remedy is economic growth. Moreover, the demographic scenarios embedded in the medium and high versions of the forecast hinder (retard) the decline in the population at working age. Preliminary estimates show that in conditions of even moderate economic growth, the increase in the life cycle deficit will decrease.

The second solution is raising the retirement age. The basis for this, from a demographic point of view, is an increase in life expectancy at older ages, an increase in the duration of the education period and, as a result, a lengthening of the period of dependency in relation to the working period in people's lives. To assess the impact of raising the retirement age, the medium scenario of the demographic forecast was used, as well as a forecast of the number of employed made at the Institute of Demography in 2017. It was assumed that the retirement age rises by one year every two years starting in 2019, until reaching the age of 65 for men and 63 for women (in accordance with the first draft of the Government of the Russian Federation, announced in June 2018). At the same time, a change in the age profile of labor income was allowed, since the period of labor activity increases and, with it, the income level in the new pre-pension and post-pension age groups increases accordingly. We assume that by the end of the transition to a new retirement age a new income model will be established. The new model was set by the average profile for countries in which the standard retirement age is 65 years for men, 60-65 years for women. It was assumed that the consumption profile throughout the entire forecast period remains unchanged. The ratio of the life cycle deficit to GDP will noticeably decrease in the period of raising the retirement age - to $3.8 \%$. It will begin to increase only after the termination of this process. But even in 2050 the share of the deficit in GDP will be relatively small - less than in other forecast scenarios in 2025. Obviously, combined with economic growth, the positive effect of raising the retirement age will be even greater. Reducing the deficit provides additional opportunities for private and public investment in human capital, as well as the accumulation of assets.

\section{SUPPORT RATIOS AND DEMOGRAPHIC DIVIDEND IN RUSSIA UP TO 2050}

National transfer accounts, by viewing economic indicators through the prism of age, measure the impact of the age structure of the population on economic dynamics and macro indicators. According to trends in NTA indicators, one can indirectly judge the economic consequences of demographic shifts. In this section, we will illustrate the "price of an aging society" for the economy, based on the so-called support ratios. 
In research practice, depending on the objectives of the study, several support ratios are used. The most common, due to the availability of data for calculating it, is the coefficient of demographic support, defined as the ratio of the number of persons in working ages to the number of persons in dependent ages. The economic support ratio can be defined as the ratio of the number of employed (or economically active) people to the number of unemployed. Due to heuristic possibilities, the effective economic support ratio has become very popular. It is a useful indicator for assessing the impact of demographic changes on economic growth and measuring the demographic dividend. The effective demographic support ratio integrates the characteristics of the age structure and age profiles of labor income and consumption.

To calculate the effective economic support ratio, two indicators are used: the effective employee and the effective consumer [Mason et al 2017: 6]. These use the average values of labor income and consumption per person in the age range from 30 to 49 years inclusive. Average values are calculated as arithmetic averages of the values of income and consumption levels in one-year age groups. The effective number of employees $L(x, t)$ is calculated by the following formula (5):

$$
\begin{aligned}
& L(t)=\sum_{0}^{\omega} \breve{y} l(x) P(x, t), \\
& \breve{y} l(x)=y l(x, b) / y l(30-49, b),
\end{aligned}
$$

where:

$y l(x, b)$ - is the labor income per person at the age of $\mathrm{x}$ and in the base year $\mathrm{b}$;

$y l(30-49, b)$ - is the average per capita income between the ages of 30 and 49;

$P(x, t)$ - is the population size at age $\mathrm{x}$ at time $\mathrm{t}$.

The effective number of consumers is calculated according to a similar scheme (formula 6):

$$
\begin{aligned}
& N(t)=\sum_{0}^{\omega} \breve{c}(x) P(x, t), \\
& \breve{c}(x)=\mathrm{c}(x, b) / \mathrm{c}(30-49, b),
\end{aligned}
$$

where:

$c(x, b)$ - is the consumption per person at the age of $\mathrm{x}$ and in the base year $\mathrm{b}$; $c(30-49, b)$ - is average per capita consumption at the age from 30 to 49 ; $P(x, t)$ - is the population size at age $\mathrm{x}$ at time $\mathrm{t}$.

The effective support ratio $S R(t)$ is calculated as the ratio of the number of effective workers to the number of effective consumers (formula 7):

$$
S R(t)=\frac{L(t)}{N(t)} .
$$

We made estimates of the three support coefficients until 2050 (Figure 4) for the medium scenario of the demographic forecast of the Institute for Demography at HSE. As can be seen, the support ratios go down. The rate of this decline will slow down due to the peculiarities of the change in the age structure in the 2030s. When calculating the demographic support ratio, the lower limit of the working age was set at the age of 20 years, the upper one - 64 years. In calculating the effective economic support, the age profiles of labor income and consumption did not change. It is obvious that the demographic support ratio exceeds all others. Indicators of economic and 
effective economic support take into account the fact that a part of the population at working age is not employed or receives a small labor income.

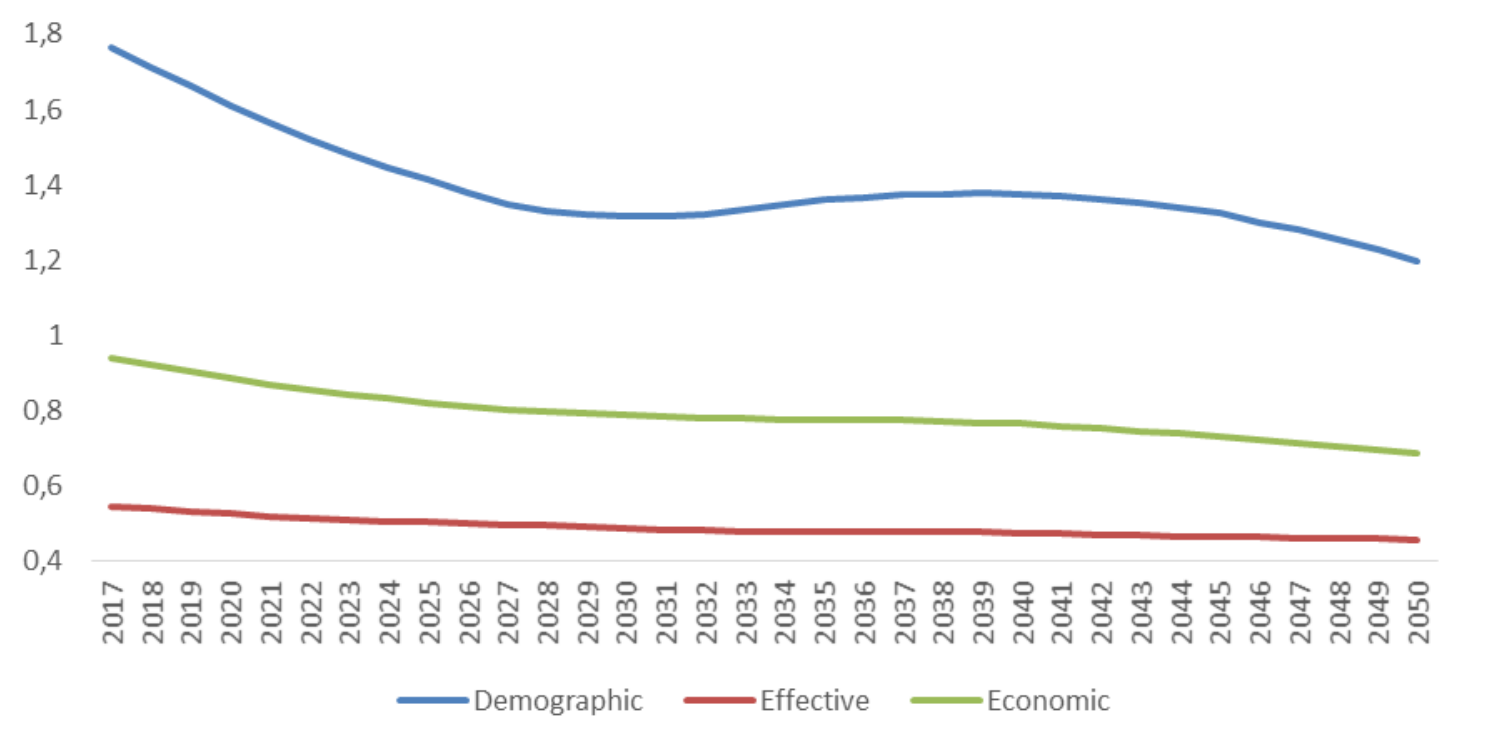

Figure 4. Support ratios, Russia, 2017-2050

Source: Authors calculations.

Using the effective economic support ratio, one can measure the first demographic dividend and determine its contribution to economic growth. The first demographic dividend is the gain that a country's economy can receive as a result of optimizing the age structure due to a decrease in the dependent (demographic) load on the working population as a result of a decrease in fertility. It appears with an increase in demographic and economic support and fades away as it declines. Optimization of the age structure is expressed in the achievement of the historical maximum of the share of persons in working ages in the total population or the historical minimum of the demographic load. To obtain a demographic dividend, institutional and economic conditions are necessary to ensure high employment and the possibility of earning labor income. According to Bloom and Williamson, about 30\% of GDP growth in China and South-East Asia is associated with a demographic dividend (Bloom, Williamson 1998).

A simple model associates the effective support ratio with the first demographic dividend (formula 8):

$$
\frac{Y(t)}{N(t)}=\frac{Y(t)}{L(t)} S R(t)
$$

In this equation, revenue per effective consumer is equal to productivity, measured by the ratio $Y(t)$ and $L(t)$ and the effect of changing the age structure, which is measured by the support ratio [Mason et al 2017: 7]. If we assume that the share of labor income in total income does not change with time, then the relative changes in labor income will coincide with the relative (in percentage terms) changes in total income. In this case, you can write this expression in the form of formula (9): 


$$
\operatorname{gr}[Y(t) / N(t)]=\operatorname{gr}[Y(t) / L(t)]+\operatorname{gr}[S R(t)],
$$

where $g r()$ indicates the growth rate of the factor, and $Y(t)$ is the total income.

The first demographic dividend is calculated as the growth rate of the support ratio. Its value directly measures the contribution of changes in the age structure to economic growth. Figure 5 presents estimates of the increase in the effective support ratio, subject to the implementation of three demographic projections, as well as the rising retirement age from 2019. Up until the early 2030s, the age structure of the population will make a negative contribution to economic dynamics. Currently, due to negative changes in the age structure, the growth rates are being reduced by about 1.3-1.5\%. At the same time, in 2019 the demographic dividend calculated by the above method will reach its minimum value. Further, the demographic dividend will increase. Moreover, in the mid-2030s the contribution of the age structure may even become positive, since the relatively numerous generations born in 2007-2016 will enter the labor market. The largest dividend is obtained under conditions of a low demographic forecast. With its implementation, the contribution of the age structure to economic growth almost throughout the 2030s will be positive. But at the same time, the effect of reducing the number of employed people must be taken into account. As was shown above, all other things being equal (excluding changes in productivity and investment in capital), GDP will decline by almost a quarter by 2050 compared to 2017. Particularly noticeable is the growth of the demographic dividend in the case of an increased retirement age. But after the end of this process, the demographic dividend sharply decreases, and then returns to the previous trend. Deviations from the trend, in particular, are related to the fact that the age profile of labor income at older ages is changing.

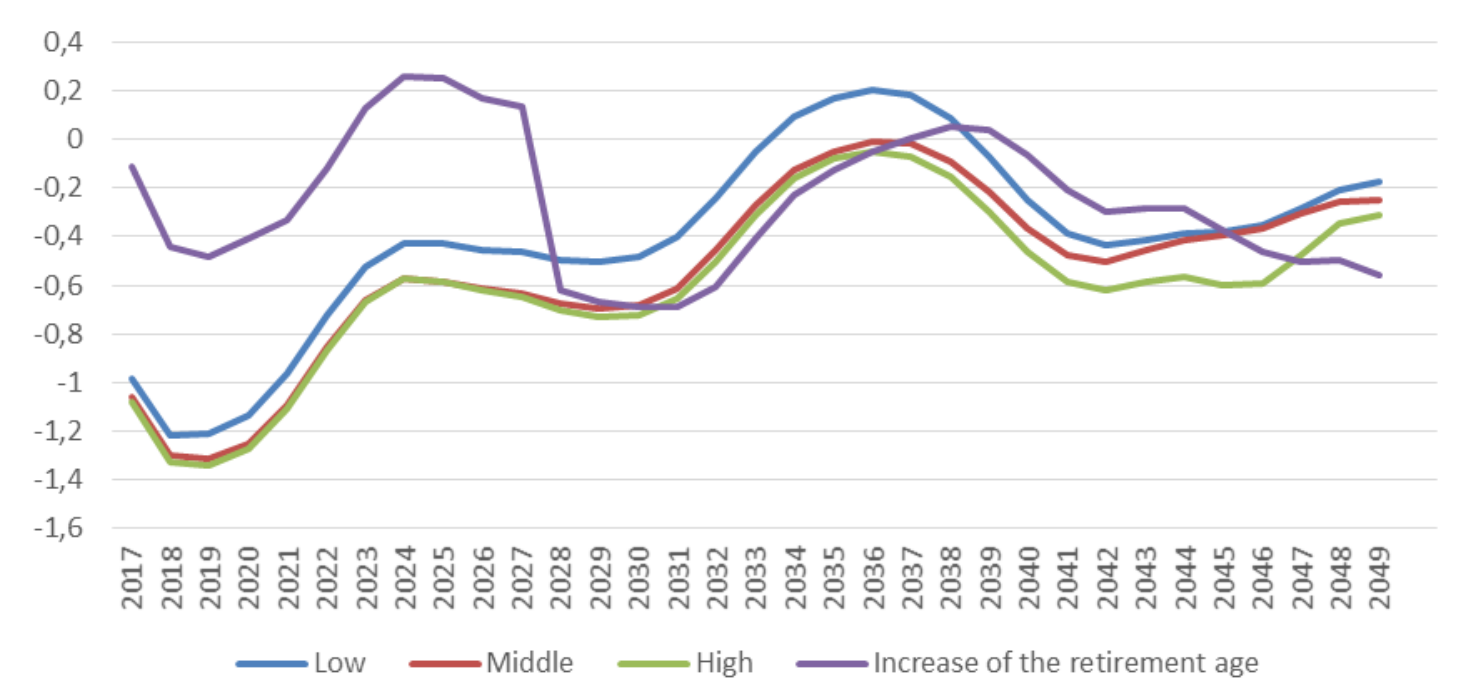

Figure 5. Demographic dividend for Russia, 2017-2049,\%

Source: Authors' calculations.

The second demographic dividend is realized if demographic changes lead to an increase in the productivity of workers. Among the various factors leading to an increase in productivity, R. Lee and A. Mason focused mainly on increased capital [Lee, Mason 2006; 2017]. The basic idea is that, as the population ages, consumption in the retirement period depends less on labor income and more on age-related redistribution of assets and transfers. An increase in the volume 
of transfers at older ages does not directly affect productivity, but an increase in assets, including the savings that older people have, can lead to an increase in investment in capital, and therefore to higher productivity. Thus, demographic changes may contribute to faster economic growth. But for this the population should actively participate in various kinds of savings projects, and the state should stimulate this participation and guarantee the safety of assets. Without these conditions, the implementation of the second demographic dividend in Russia will be impossible.

\section{Conclusion}

The aging of the population is creating many challenges for the social institutions of modern society that emerged during the period of "demographic youth". When making decisions in the socio-economic sphere, taking demographic changes into account is extremely important, and the assessment of their consequences is one of the key areas of modern research in economic demography. However, despite the importance of the demographic factor, the standard indicators of economic development adopted in the modern world have long been developed mainly in relation to the entire population, and do not reflect the contribution of certain age groups or generations to total production and consumption. The calculations made by the authors within the framework of this paper are the first attempt in Russia to estimate the contribution of various age groups to the production and distribution of national income using the system of national transfer (intergenerational) accounts (NTA). As a result, it turned out to be possible to calculate the life cycle deficit, the effective support rates and the demographic dividend in Russia until 2050.

National transfer accounts are a modern methodology for measuring the impact of demographic factors on a country's economy. In particular, they make it possible to assess the difficult role of the older population in economic development as consumers, producers, investors, recipients and sources of transfers, etc. It is currently not possible to carry out such an assessment using other methods of analyzing the effects of aging. In the framework of the standard model of national transfer accounts, economic flows are divided into age groups. The development of such a model makes it possible to disaggregate these flows also by gender, education level and other characteristics of the population. Moreover, modern approaches to their construction make it possible to overcome one of the limitations of the system of national accounts, namely, the underaccounting of services that households produce for themselves. With the help of indicators of age-related time budgets, non-market activities of household members can be included within the system of national transfer accounts. All this opens up new prospects for economic and demographic research in Russia.

\section{ACKNOWLEDGMENTS}

The authors are grateful to Robert Gal (Institute of Demography, Hungary) for valuable recommendations, and to A.G. Nazarova and A.V. Chernyavsky (Institute of Development, HSE) for their help in assessing the aggregated indicators of the system of national transfer accounts for Russia. 


\section{REFERENCES}

Andreev E.M., L.E. Darsky (1986). Ekonomiko-demograficheskie protsessy v real'nykh pokoleniyakh [Economic and demographic processes in generations] // Demograficheskie protsessy i ikh zakonomernosti [Demographic processes and their patterns] / A.G. Volkov, ed. Moscow: Mysl’: 10-21.

Arthur W.B., G. McNicoll (1978). Samuelson, population and intergenerational transfers // International Economic Review. 241-246.

Auerbach A.J., J. Gokhale, L.J. Kotlikoff (1994). Generational accounting: a meaningful way to evaluate fiscal policy // Journal of Economic Perspectives. 8(1): 73-94.

Barro R.D., X. Sala-i-Martin (2004). Ekonomicheskiy rost [Economic growth]. Moscow: BINOM. Laboratoriya znaniy. 824 p.

Barro R.J. (1974). Are government bonds net wealth? // Journal of Political Economy. 82(6): 1095-1117.

Bloom D., D. Canning, J. Sevilla (2003). The demographic dividend: a new perspective on the economic consequences of population change. RAND Corporation. $127 \mathrm{p}$.

Bloom D., D. Canning, P. Malaney (2000). Demographic change and economic growth in Asia // Population and Development Review. 26 (Suppl.): 257-290.

Bloom D.E., J.G. Williamson (1998). Demographic transitions and economic miracles in emerging Asia // World Bank Economic Review. 12(3): 419 - 455.

Bommier A., R. Lee, T. Miller, S. Zuber (2010). Who wins and who loses? Public transfer accounts for US generations born 1850 to 2090 // Population and Development Review. 36(1): 1-26.

Caldwell J.C. (1982). Theory of Fertility Decline. New York: Academic Press. 386 p.

Chayanov A. (1989). Krest'yanskoe khozyaystvo [Peasant economy]. Izbrannye trudy [Selected works]. Moscow: Economica. 492 p.

D’Albis H., D. Moosa (2015). Generational economics and the national transfer accounts // Journal of Demographic Economics. 81(4): 409-441.

Diamond P. (1965). National debt in neoclassical growth model // The American Economic Review. 55(5): 1126-1150.

Feldstein M. (1974). Social security, induced retirement, and aggregate capital accumulation // Journal of Political Economy. 82(5): 905-926.

Goryunov E., L. Kotlikoff, S. Sinelnikov-Murylev (2015). Teoreticheskie osnovy byudzhetnogo razryva kak pokazatelya dolgosrochnoy fiskal'noy ustoychivosti i ego otsenka dlya Rossii [Theoretical foundations of fiscal gap as a long-term fiscal sustainability indicator and its estimates for Russia]. Moscow: Institut ekonomicheskoy politiki im. E.T. Gaydara: 60 p.

Kotlikoff L. (1992). Generational Accounting-Knowing Who Pays, and When, for What we Spend. New York: Free Press. 261 p.

Kotlikoff L.J., L.H. Summers (1981). The role of intergenerational transfers in aggregate capital accumulation // Journal of Political Economy. 89(4): 706-732.

Lee R., A. Mason (2006). Chto takoe demograficheskiy dividend? [What does it mean demographic dividend?] // Finansy i razvitie [Finance and Development]. URL: https://ntaccounts.org/doc/repository/LM2006_Russian.pdf (accessed: 22.12.2018). 
Lee R., A. Mason (2011). Population aging and generational economics: key findings // Population Aging and the Generational Economy / R. Lee, A. Mason, eds. Cheltenham, UK: Edward Elgar Publishing: 3-31.

Lee R., A. Mason (2017). Tsena stareniya [Cost of aging] // Finansy i razvitie [Finance and Development]. URL: https://www.imf.org/external/russian/pubs/ft/fandd/2017/03/pdf/lee.pdf (accessed: 22.12.2018).

Lee R., T. Miller (2000). Immigration, social security, and broader fiscal impacts // American Economic Review. 90(2): 350-354.

Lee R., W. Arthur, G. Rodgers (eds) (1988). Economics of Changing Age Distribution in Developed Countries. New York: Oxford University Press. 221 p.

Lee R.D. (1980). Aiming at a moving target: Period fertility and changing reproductive goals // Population Studies. 34(2): 205-226.

Lee R.D. (1994). The formal demography of population aging, transfers, and the economic life cycle // Demography of aging: 8-49.

Lee R.D., S. Tuljapurkar (2000). Population forecasting for fiscal planning: Issues and innovations // Demography and Fiscal Policy / A. Auerbach, R. Lee, eds. Cambridge University Press: 7-57.

Mason A. (1988). Saving, economic growth, and demographic change // Population and Development Review. 14: 113-144.

Mason A., M. Lee, M. Abrigo, S. Lee (2017). Support Ratios and Demographic Dividends: Estimates for the World. New York (NY): Population Division, United Nations. 52 p.

Modigliani F. (1988). The role of intergenerational transfers and life cycle saving in the accumulation of wealth // Journal of Economic Perspectives. 2(2): 15-40.

Modigliani F., R. Brumberg (1954). Utility Analysis and the Consumption Function: An Interpretation of Cross Section Data // Post Keynesian Economics, ed. by K.K.Kurihara. Ruthers University Press New Brunswick New Jersey: 388-436.

Natsional'nye scheta Rossii v 2006-2013 godakh [National Accounts in Russia in 2006-2013] (2013). Statisticheskiy sbornik [Statistical Yearbook]. Moscow: Rosstat. URL: http://www.gks.ru/wps/wcm/connect/rosstat_main/rosstat/ru/statistics/publications/catalog/do c_1135087050375 (accessed: 22.12.2018).

Prskawetz A., J. Sambt (2014). Economic support ratios and the demographic dividend in Europe // Demographic Research. 30: 963-1010.

Samuelson P. (1958). An exact consumption loan model of interest with or without the social contrivance of money // Journal of Political Economy. 66(6): 467-482.

Sauvy A. (1977). Obshchaya teoriya naseleniya [General population theory]. T.1. [V.1]. Moscow: Progress. 503 p.

Sistema natsional'nykh schetov 2008 [System of national accounts 2008] (2012). UN, European Commission, IMF, OECD, World Bank. New York. 827 p.

Temple J., J. Rice, P. McDonald (2017). Economics of Ageing Feature. Ageing and the economic life cycle: The National Transfer Accounts approach // Australian Journal of Aging. 36(4): 271-278.

United Nations (2013). National transfer accounts manual: Measuring and analysing the generational economy. New-York: United Nations. 
Urlanis B.C. (1971). Ekonomicheskie aspekty demografii [Economic aspects of demography] // Problemy demografii [Demographic problems] // D.L. Broner, I.G. Venetskiy, eds. Moscow: 93-110.

Urlanis B.C. (1976). Narodonaselenie, issledovanie, publitsistika [Population, researches and essays]. Moscow: Statistika. 255 p.

Valkovics E. (1971). Ekonomicheskie vozrastnye piramidy [Economic age pyramids] // Marksistsko-leninskaya teoriya narodonaseleniya [Marx-Lenin population theory] / D. Valentei, ed. Moscow: Prosveshchenie: 127-149.

Willis R.J. (1988). Life cycles institutions and population growth: a theory of the equilibrium interest rate in an overlapping generations model // Economics of Changing Age Distribution in Developed Countries / R. Lee, W. Arthur, G. Rodgers, eds. New York: Oxford University Press: 106-138. 